\title{
Being Pakeha: The Politics of Location
}

\section{LYDIA WEVERS}

\section{Victoria University of Wellington}

In an election blog published in the New Zealand Herald (23 August 2005), Alistair Kwun noted:

Voters of Asian descent will have their say in this year's election for sure. . . . three switched-on young Chinese shared their thoughts on this year's election on Nightline - two 1.5 generation Taiwanese, and one New Zealand-born. They got a kick out of being interviewed, and it's a testament to how far the public discourse has come. Five years ago nobody would have bothered wanting to know what their opinions actually were. ${ }^{1}$

One of the distinguishing features of the 2005 election campaign was the visibility of multicultural and bicultural tensions in New Zealand. Collectivist rhetoric like 'mainstream' or 'all New Zealanders' is always fast off political lips during an election, but in 2005, shadowed by contentious events of the last few years, notably the Foreshore and Seabed legislation, ${ }^{2}$ Ahmed Zaoui's struggle to validate his refugee status ${ }^{3}$ and the Civil Union Bill, ${ }^{4}$ the nation revealed itself to be quarrelsome, anxious, divided and embedded in familiar cultural, diasporic and post-colonial dilemmas. When the former Leader of the Opposition, Dr Don Brash, was asked to spell out what he meant by 'mainstream', he declined but referred to unnamed minority groups the government was 'pandering' to and finally mentioned funding targeted to Maori. Asked if 'mainstream' included gay people, he said, 'Well, they're clearly not, they're a small minority of people', ${ }^{5}$ then seeing the blind alley walls looming, he added, 'I'm sure some of them absolutely are'.

Brash's political rhetoric may have been more mealy mouthed and inarticulate than some of his fellow travellers, but it reflected a heightened level of political dissent and dis-ease in New Zealand about citizenship, social values, culturalisms and equity, and in its further extremes is a discourse of racism and materialism. It is a discourse echoed in the government's insistence that need, not race, must underpin social and economic policy; in a Cabinet Minister's claim that being born in Wainuiomata, a workingclass suburb of Wellington, makes him indigenous; ${ }^{6}$ and in the numerous 
challenges made to white New Zealand's image of itself as tolerant and fair by Maori, Asian and Pacific communities. But it is also true to say that the dilemmas and the politics of identity are no more or less contested in Aotearoa New Zealand than in any other post-colonial settler society. From the far reaches of anti-treatyism to newspaper articles about a woman who cut herself in court to prove she could bleed like a Maori, identity politics work to yoke or unyoke ethnicity, sexuality, citizenship, nationality, history and culture - the overarching questions posed by post-colonial histories and narratives about belonging, about rights, about territory and nation that continue to put problems as choices, and uneasily fail to evade or clarify debates like the one that is the subject of this conference.

What interests me is how to occupy the space of my own intellectual work and what it means to be Pakeha without falling into the politics of blame, or of guilt, or what Ghassan Hage has termed 'white-and-very-worried-about the-nation-subject'. ${ }^{8}$ Hage's unpicking of the subtly racist differentiations of white liberalism has many applications. Being Pakeha is itself a privileging position, a frankly indigenizing claim, nowhere more clearly demonstrated than in the popular and influential memoir-texts of New Zealand historian Michael King, Being Pakeha ${ }^{9}$ and Being Pakeha Now. ${ }^{10}$

I became the Director of the Stout Research Centre at Victoria University in 2001. Despite its claim on the letterhead to pursue scholarly enquiry into the society, history and culture of New Zealand, there seemed to be a few definitional problems around the Stout Centre's name, including its being listed in an international guide to brewing. I began by changing the name to Stout Research Centre for New Zealand Studies, still problematic, but it seemed to me a good way of holding out the promise of interdisciplinary work, working between and across more defined fields of enquiry, and of building a strong local focus which did not exclude the many shifts and connections across boundaries, geographies and cultures that characterise post-modern and post-colonial societies. And to a large extent this explicit move to produce interdisciplinary and cross-cultural work has been successful, including the generation of interest in and enquiry into diaspora, migration, citizenship, and New Zealand's history and demography as a postcolonial multicultural society. But the difficult part of the Stout Research Centre's work is, and continues to be, biculturalism. Although a unit of the Stout Centre specialises in contract work on Treaty claims and research into Crown/Maori relations, the wider questions raised by an official bicultural policy and the intellectual and scholarly dimensions of biculturalism remain largely unanswered. For a start, who is included in New Zealand studies? And if the name becomes Aotearoa studies, who and what is the object of study? What is the knowledge system or, rather, what are the knowledge 
systems? And whose is the content? How do we approach biculturalism without being appropriative, paternalistic or schematic? And what is the practice of Pakeha scholars working in New Zealand studies?

To assert a post-colonial practice is to run into the familiar cognitive and conceptual constraints identified by many post-colonial critics: the risks of speaking for rather than speaking against, of over-categorising and creating a politics of difference whose role is descriptive rather than critical, of failing to move beyond established knowledge systems or institutional practices. Yet without a post-colonial practice, a practice that is politically engaged, a scholarship that attempts to move beyond identifying the problem, we cannot have biculturalism or multiculturalism, and it seems to me that at the heart of this, somewhere, lies a hard and necessary look at what it means to 'be' Pakeha. Is there a cultural category in which someone like me sits, or is it rather a political place from which scholarly and critical objectives are formulated and pursued?

Most bicultural discussion in Aotearoa New Zealand is still anchored to the Treaty of Waitangi. Implementing the Treaty has been foundational to recent government and local body policy, and Treaty discourse and Treaty backlash are a familiar and highly charged part of our political landscape. In the language of the Treaty, Maori and the Crown are Treaty partners and many Maori interpret this quite literally as the Queen, represented in the government. What is my responsibility, as a Pakeha, to the Treaty and to being the collective other signalled symbolically in the person of Elizabeth Windsor via Helen Clark? There is a kind of shift in Treaty negotiations that allows us to leave the settlements and their history, the Treaty implementation and what it means as a tool of a real, politically engaged and materially evident biculturalism, out there for institutions and agencies to negotiate. How do Pakeha and Crown connect? Are they an entity, participating in the dialogue of Crown and Maori, Pakeha and Maori? These are perhaps questions to ask rather than answer - and I am mindful of Gayatri Chakravorty Spivak's point that the practice of 'speaking as' always involves a distancing from oneself, ${ }^{11}$ and in this respect speaking as the Crown, or as Pakeha, Maori, a woman, a university employee or a conference-goer illustrates the contingency and indeterminacy of most speaking positions. But there is a politics here which is germane, and if being Pakeha as a speaking position reflects anything, it should reflect a politics of location, and of culturalisms, which is neither disingenuous nor romanticised.

When Michael King died in 2004, there was a lot of comment about the untimeliness of his accidental death, not only that he seemed too young but also that his was a voice (a voice of 'reason') which would be missed in the 
fierce debates around the Foreshore and Seabed legislation and what was shaping up to be a major standoff between Maori and Pakeha over rights, claims and identity. King's career, and his consciousness-raising about the Maori dimensions of a New Zealand which largely ignored them for most of the twentieth century, are eloquently described in his autobiographical Being Pakeha and its later version Being Pakeha Now, published in 1999. In his introduction, fellow historian Kerry Howe says that Being Pakeha Now may be King's most important book, because it describes a journey which, in Howe's words, 'is in many ways archetypal'.

Being Pakeha Now is a warm and modest account of an exceptional life story. Subtitled 'Reflections and Recollections of a White Native', a term that is reasonably dis-comforting these days, the cover features a quotation from near the end in which King claims that 'Pakeha New Zealanders who are committed to this land and its people are no less indigenous than Maori', and his text's project is to demonstrate how this might be the case. One of the points he makes, by way of an extended genealogy of family and childhood, is that Pakeha is a relatively recently-adopted term of self-description by European New Zealanders. As a child, King remarks, with strongly Irish antecedents, he would not have called himself Pakeha. Instead, his claim to indigeneity begins, as all stories of nativism do, with childhood and landscape, a comforting internalization connecting innocence and land. As he fell asleep at night listening to the cry of the oystercatchers, he experienced an 'immensely comforting feeling that I was part of nature and nature part of me'. As anyone who has read Katherine Mansfield, Janet Frame or Maurice Gee will recognise, this is the heartland of Pakeha cultural imaginary, not always a reassuring identification, often problematized, troubled or darkly dystopic, but a stake planted firmly in the ground nonetheless.

What makes King unusual is his early recognition that Maori history and the realities of Maori life were invisible to most Pakeha, that in order to access them he had to become fluent in te reo Maori and understand tikanga and kaupapa Maori, and that a great deal of oral history was vanishing. His early books, Moko: Maori Tattooing in the 20th Century, ${ }^{12}$ Te Ao Hurihuri: The World Moves On: Aspects of Maoritanga, ${ }^{13}$ a biography of Te Puea ${ }^{14}$ and Maori: A Photographic and Social History, ${ }^{15}$ reflect a powerful selffashioning: anti-racist, bicultural and Pakeha. So what is troubling about this story? It is in many respects admirable - King shows himself to be open-minded, socially responsible, hardworking, and honestly committed to knowing and understanding another culture, and the response to his sudden accidental death, which was national and deeply emotional, confirmed a widely-held affection for him and for his work. 
About half way through his career and in response to increasingly urgent and outspoken Maori criticism of his role as an historian of their culture, King stopped working on Maori subjects and never returned to them. In Being Pakeha Now, he describes the politics that he encountered in the 1980 s, an identity politics reflecting the theoretical and cultural shifts that accompanied post-colonialism, feminism and post-modernism. He quotes Keri Kaa, who, reviewing King's Maori: A Photographic and Social History in the New Zealand Listener, said:

We have kept quiet for too long about how we truly feel about what is written about us by people from another culture. For years we have provided academic ethnic fodder for research and researchers. Perhaps it is time we set things straight by getting down to the enormous task of writing about ourselves. ${ }^{16}$

This is King's response:

Nobody would answer what seemed to me to be the most relevant question: would anything be different in the book (apart from the selection of photographs) if it had been written by a Maori? I doubted it. I had focused the text on Maori viewpoints from Maori sources. ${ }^{17}$

I do not think I need laboriously to unpack why concepts of authority, biculturalism, Pakeha and indigenous become urgent here, or why they might be accompanied by ideas about the subaltern or speaking position; it is enough simply to recall Franz Fanon's description of arriving in Lyons from Martinique:

I came into the world imbued with the will to find a meaning in things, my spirit filled with the desire to attain to the source of the world, and then I found that I was an object in the midst of other objects. ${ }^{18}$

What is troubling about King's journey into another culture and its history, well intentioned as it is, curious, eager to learn, ready to listen, is that he does not understand his role. Without a mechanism of reflexivity, he speaks from a position which simply substitutes his voice for his subject's, a voice which in speaking for Maori also contains and overwrites them. It is not a palimpsest, in Zygmunt Baumann's terms, ${ }^{19}$ but an assimilation: King's claim to be indistinguishable from Maori erases the permissions and negotiations which have allowed him to access knowledge in the first place, a significant part of his autobiographical memoir and claim to authority, and draws attention to the evident fact that even the most indigenized western subject can never become indigenous. Ien Ang, writing about why she chose to use autobiography as a methodology in unpacking identity politics, diasporic identifications and post-modern ethnicity, remarks, 
... what is at stake in autobiographical discourse is not a question of the subject's authentic 'me' but one of the subject's location in a world through an active interpretation of experiences that one calls one's own in particular, 'worldly' contexts, that is to say, a reflexive positioning of oneself in history and culture. ${ }^{20}$

In some senses, this is what King's autobiographical narrative sets out to do. He positions himself in history and culture as a Pakeha, but where a reflexive positioning might have revealed the ways in which he could not produce knowledge except at a remove and by permission of Maori, he chooses to flatten out difference in favour of mimicry, a Pakeha who is Pakeha through his ability to assume the place of, and speak for, his subjects. In his Author's Note, King explains why he wrote Being Pakeha:

It seemed to me, the most important task facing a historian of my background was to make Maori preoccupations and expectations intelligible to pakeha New Zealanders; to make it clear why I believed that Maori had every right to be Maori in their own country and to expect pakeha to respect them.

The second version, Being Pakeha Now, almost 20 years later, takes the opposite view: 'a rather different but equally pressing need . . . to explain pakeha New Zealanders to Maori and to themselves; and to do this in terms of their right to live in this country, practise their values and culture and be themselves'.

Both these intentions seem to me to fall into what Ghassan Hage describes as managing the nationalist space or the discourse of limits. Hage invokes both evil and good white nationalists, broadly speaking, a distinction between racists and those who argue for tolerance and the companion values of liberalism. King is clearly in the latter camp, but what his expressed authorial intentions reveal is what Hage has called the 'power of the dominant to set their own . . . boundaries'. ${ }^{21}$ Hage is referring to spatial control of the tolerated (or not tolerated) other; King is articulating a set of discursive and moral imperatives which position him as the authoritative interpreter, the historian who controls the explanation, the discourse and its reception and who speaks for two cultures.

Many Pakeha New Zealanders have responded positively to King's book. Their approval is a recognition that he did in his life something that shamefully few New Zealanders attempt, fluency in another language and culture, but it also reflects the reassurance offered in what Ghassan Hage, following Bourdieu, has called a 'form of symbolic violence in which a mode of domination is presented as a form of egalitarianism'. ${ }^{22}$ King's Maoritanga, his capacity to speak te reo and aim to redress Pakeha ignorance of Maori 
history and culture, do not overcome his dominant culture assumptions. He assumes the role of magisterial historian, whose explanations and beliefs will enlighten the ignorant and speak for a silenced Maori. Bourdieu describes this as 'strategies of condescension . . . by which agents occupying a higher position in one of the hierarchies of objective space symbolically deny the social distance which does not thereby cease to exist thus ensuring they gain the profits of recognition'. ${ }^{23}$ King's narrative composes itself at the intersection between the advantages of proximity and the advantages of distance, and becomes an active participant in a Pakeha discourse of rights, entitlement and belonging.

For me, Being Pakeha Now throws into sharp relief questions surrounding the use of 'Pakeha' as a self descriptor. 'Pakeha' is a term that has meaning only in relation to Maori. It refers to European New Zealanders who settled in Aotearoa and was a collective name given to them by the indigenous people. In that sense, it cannot be interchanged with indigenous, or with native. Pakeha is not the same as foreigner - tau iwi in Maori. The Reed Dictionary of Modern Maori defines it as non-Maori, European, Caucasian; ${ }^{24}$ Wikipedia concurs: 'Pākehā is a New Zealand English word for European New Zealanders, that is, New Zealanders of predominantly European descent ${ }^{25}$ King, as Jody Ranford points out in a recent essay, ${ }^{26}$ defines Pakeha as 'denoting non-Maori New Zealanders', but the current political discourse of limits which insists on Asian, Pacific and other subgroup identifiers refers Pakeha back to the Wikipedia and Reed definitions. So how can we read Pakeha as a referent, a signifier, an identity that is not the same as European New Zealander, or Kiwi or white? Does it have any use, or, by adopting it, do we inevitably fall into strategies of condescension? What is its role in biculturalism and in multiculturalism?

It seems to me that Ien Ang is helpful here for sketching out a bit of the imagined community of bicultural Aotearoa. Thinking about the precariousness of her Chineseness, Ang notes that since diasporas are -

... fundamentally and inevitably transnational in their scope, always linking the local and the global, the here and the there, past and present, they have the potential to unsettle static, essentialist and totalitarian conceptions of 'national culture' and 'national identity' which are firmly rooted in geography and history. But in order to seize on that potential, diasporas should make the most of their complex and flexible positioning. ${ }^{27}$

The cultural history of European New Zealand has been preoccupied with figuring a national identity which yokes together the here and the there, both historically and geographically, which aims to achieve what Linda Hardy 
has called 'natural occupancy'. ${ }^{28}$ To a large extent this has meant rejecting an unsettled diasporic subjectivity in favour of a settled nativism. Indeed, bicultural policy has been about reinserting indigenous culture into the monocultural norm. If 'Pakeha' is to be more than the 'innocent reflection of a natural reality that is passively waiting to be discovered', to borrow Ang's words, ${ }^{29}$ then it too should actively adopt the complex positioning of a diasporic identity. If bicultural is to have purchase on people's lives, the dominant culture, a culture which is both a tool and a function of power, has to understand itself as having been brought into being by its relation to the Treaty, to indigenous culture, Pakeha to Maori. This is already, and will continue to be, a layered and contested discourse, but what it shows is that Pakeha is not a fixed and given category of identity but rather one that exists in negotiation with the history and geography of the Treaty and with their social and economic consequences. If Pakeha could understand itself as a conferred identity, an identity that has meaning in relation to its 'other' term, Maori, and to our shared history and evolving, diverse, unequal society, it might suggest we do not take so much for granted and learn to overcome our monoculturalism and normative thinking.

Dipesh Chakrabarty, discussing utopian subaltern radicalism, comments that it allows a move away from the "knowing, judging, willing subject [who] already knows what is good for everybody, towards a radical openness, the capacity to hear that which one does not already understand ${ }^{30}$ The problem with biculturalism has always been its focus on culturalism, when what it is really implementing is a loaded encounter between power and culture: culture as 'other' is allowed to enter the house of power. If Pakeha are to acculturate themselves to a more radical negotiation of post-colonial New Zealand modernity, it is time to make culture powerful, to hear what you do not already understand and to hear it from a place where being Pakeha is not an expression of fear and entitlement but an acceptance of a foundational relationship which describes why we choose to be here, the grounds on which we are here and what we should do about it. Being Pakeha is not about becoming indigenous, it is about the engagement we committed to a long time ago.

1 New Zealand Herald, 23 August 2005, http://www.nzherald.co.nz/event/story.cfm?c_id $=1500891$ \&objectid $=10341906$

2 Foreshore and Seabed Act 2004.

3 Refugee Status Appeals Authority New Zealand refugee appeal no. 74540, 1 August 2003, Human Rights Foundation, Auckland, 2005.

4 Civil Union Bill 2004. 
5 No Right Turn: Don Brash \& The Politics Of Division, Monday, 27 June 2005, http:// www.scoop.co.nz/stories/print.html?path=HL0506/S00372.htm

6 Hon Trevor Mallard, 'We Are All New Zealanders Now', speech hosted by Stout Research Centre for New Zealand Studies, Victoria University of Wellington, 28 July 2004. Reported in 'We are all indigenous now', Dominion Post, 29 July 2004, p.1.

7 'Biculturalism or Multiculturalism', University of Canterbury, Christchurch, 1-3 September 2005 .

8 Ghassan Hage, White Nation: Fantasies of White Supremacy in a Multicultural Society, New York, 2000, p.10.

9 Michael King, Being Pakeha: An Encounter with New Zealand and the Maori Renaissance, Auckland, 1988.

10 Michael King, Being Pakeha Now: Reflections and Recollections of a White Native, Auckland, 1999.

11 Gayatri Chakravorty Spivak, 'Questions of Multiculturalism', in Sarah Harasym (ed.), The Postcolonial Critic, New York \& London, 1990, p.60.

12 Michael King, Moko: Maori Tattooing in the 20th Century, Auckland, 1972.

13 Michael King, Te Ao Hurihuri: The World Moves On: Aspects of Maoritanga, Wellington, 1977.

14 Michael King, Te Puea, A Biography, Auckland, 1977.

15 Michael King, Maori: A Photographic and Social History, Auckland, 1984.

16 Keri Kaa, cited in King, Being Pakeha Now, p.184.

17 King's response, ibid., p.184.

18 Franz Fanon, Black Skins White Masks, tr. Charles Lam Markmann, London, 1968, p.77.

19 Zygmunt Baumann (Postmodernity and its Discontents, New York, 1997, p.25) describes the 'palimpsest identity' as 'the kind of identity which fits the world in which the art of forgetting is an asset'.

20 Ien Ang, On Not Speaking Chinese: Living Between Asia and the West, New York, 2002, pp.23-24.

21 Hage, White Nation, p.91.

22 Ibid., p.87.

23 Pierre Bourdieu, In Other Words: Essays towards a Reflexive Sociology, Cambridge, 1990, pp.127-8, cited in Hage, White Nation, p.87.

24 P.M. Ryan, The Reed Dictionary of Modern Maori, Auckland, 1997.

25 http://en.wikipedia.org/wiki/Pakeha

26 Jodie Ranford, 'Pakeha, its origin and meaning', http://maorinews.com/writings/papers/ other/pakeha.htm

27 Ang, On Not Speaking Chinese, pp.34-35.

28 Linda Hardy, 'Natural Occupancy', in Suvendrini Perera (ed.), Asian \& Pacific Inscriptions: Identities, Ethnicities, Nationalities, Victoria, 1995, pp.213-28.

29 Ang, On Not Speaking Chinese, p.39.

30 Dipesh Chakrabarty, Habitations of Modernity. Essays in the Wake of Subaltern Studies, Chicago and London, 2002, p.36. 